Discussion Paper No. 07-053

\title{
Self-Productivity in Early Childhood
}

Katja Coneus and Friedhelm Pfeiffer

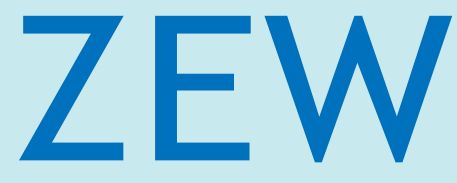

Zentrum für Europäische Wirtschaftsforschung $\mathrm{GmbH}$

Centre for European

Economic Research 
Discussion Paper No. 07-053

\title{
Self-Productivity in Early Childhood
}

\author{
Katja Coneus and Friedhelm Pfeiffer
}

Download this ZEW Discussion Paper from our ftp server:

ftp://ftp.zew.de/pub/zew-docs/dp/dp07053.pdf

Die Discussion Papers dienen einer möglichst schnellen Verbreitung von neueren Forschungsarbeiten des ZEW. Die Beiträge liegen in alleiniger Verantwortung der Autoren und stellen nicht notwendigerweise die Meinung des ZEW dar.

Discussion Papers are intended to make results of ZEW research promptly available to other economists in order to encourage discussion and suggestions for revisions. The authors are solely responsible for the contents which do not necessarily represent the opinion of the ZEW. 


\section{Non technical summary}

Cognitive and noncognitive skills are created in the interaction of the child with parents and the environment in early childhood. Self-productivity is the fundamental principle of skill formation. It means that skills acquired at one stage in the life cycle enhance skill formation at later stages. Self-productivity in association with the dramatic speed of learning and skill formation is the main reason that early childhood has a shaping role for human capital formation and inequality over the life cycle. Successful skill acquisition leads to further success and one important reason behind a failure in school and the labor market is a failure of capacity formation in early childhood.

In this study we investigate self-productivity within a three stage skill formation model in early childhood. Based on the representative German Socio-Economic Panel for the years 2002-2005, indicators of cognitive and noncognitive skills are observed from birth until the age of three years. So the paper sheds empirical light on the magnitude of self-productivity and the intergenerational transmission of human capital in early childhood. Our findings indicate that both, acquired skills at previous stage and parental investments, contribute to the skill formation process. The magnitude of self-productivity varies between skills and developmental stages. Evaluated at the sample mean a one percent increase in birth weight leads to a 0.34 percent increase in child's noncognitive skills and to a 0.64 percent increase in child's health until the age of 18 months. Between the second and third stage, a one percent increase in child's noncognitive skills leads to a 0.58 percent increase in child's verbal skills and to a 1.04 percent increase in child's everyday skills. The empirical results suggest strong synergies between child's health and child's noncognitive skills.

Parents who pay attention to a regular interaction with their child and a regular meal improve noncognitive skills, which deepens further skill formation through selfproductivity. Our investigation helps to understand skill formation in early childhood and the causality behind the intergenerational transmission of human capital and inequality. The significant magnitude of self-productivity in early childhood suggests that strong compensatory effort is needed to help disadvantaged children already in the first three years. Improvements in nutrition for eliminating birth weight differences will be more effective if they are combined with adequate postnatal parental investments. The findings suggest that for fostering human capital more attention should be paid to the quality of early parent-child interaction. This includes emotion and nutrition. 


\title{
Self-Productivity in Early Childhood
}

\author{
Katja Coneus*, Friedhelm Pfeiffer ${ }^{\dagger}$
}

September 13, 2007

\begin{abstract}
Self-productivity is a crucial feature in the process of skill formation. It means that skills and health acquired at one stage in the life cycle enhance skills and health formation at later stages. This paper presents an empirical investigation of self-productivity in early childhood in Germany. The data are drawn from the mother-child questionnaire of the German Socio-Economic Panel for the birth cohorts 2002-2005. The magnitude of self-productivity varies between skills and over time. A one percent increase in birth weight increase child's noncognitive skills by 0.34 percent and child's health by 0.64 percent at the age of 3-18 months. Until the age of 42 months a one percent increases in child's noncognitive skills enhances child's verbal skills by 0.57 percent and child's everyday skills by 1.04 percent. Furthermore, our estimates suggest synergies between child's health and child's noncognitive skills.
\end{abstract}

Keywords: self-productivity, early childhood, skill formation, birth weight, health JEL-classification: I20, J13, J24

Acknowledgements: Friedhelm Pfeiffer acknowledges financial support from the German Research Foundation under grants PF 331/2 ("Microeconometric Methods to Assess Heterogeneous Returns to Education") and PF 331/3 ("Wages, Rent-Sharing and Collective Wage Bargaining"). For helpful discussions we thank Irene Bertschek, Paul Bingley, Janet Currie, Johannes Gernandt, Grit Mühler, Niels Westergaard-Nielson and Marianne Saam. All remaining errors are ours.

\footnotetext{
${ }^{*}$ Centre for European Economic Research, Mannheim.

$\dagger$ Centre for European Economic Research and University of Mannheim. Corresponding author: P.O. Box 103443, D-68034 Mannheim, Tel.: +49-621-1235-150, E-mail: pfeiffer@zew.de.
} 


\section{Introduction}

The formation of cognitive skills (memory, learning, information speed, verbal skills) and noncognitive skills (motivation, volition, persistence, social skills) is a cumulative and synergetic process, which starts in the womb and is influenced by inherited as well as created abilities (Cunha and Heckman; 2007). The early years in the development of skills are crucial because of the dramatic speed of the brain development and learning and because of self-productivity. Self-productivity is the essential feature in the process of skill formation, which postulates that skills and health acquired at one stage in the development process enhance skill and health formation at later stages (Cunha et al.; 2006). Varied experience in early childhood thus lays the foundation to some extent for success or failure in school and labor market and for human capital formation in later life.

Empirical analysis of self-productivity in early childhood and throughout the life cycle is still hampered by a lack of representative data. Measurement of several constructs of skills, for instance intelligence and motivation, at different development stages from early childhood to adulthood are costly and may nevertheless remain ambivalent, in particular for young and very young children. Collecting data for skills over the life cycle together with the main skill formation factors (investments by parents, school, peer groups etc.) is a task of intensive ongoing research. Given the importance of self-productivity in early childhood and its long run multiplier effects for human capital accumulation, quantitative knowledge on its magnitude is a prerequisite for the formulation of compensational policies.

Using the German Socio-Economic Panel (GSOEP), we empirically assess selfproductivity in a three stage developmental process. Our contribution to the burgeoning empirical literature on self-productivity (Cunha and Heckman; 2006; Cunha et al.; n.d.) in early childhood is threefold. First, the paper presents a quantitative assessment of the feature self-productivity in the first three years of an children's life. Second, we compare the returns of investments on skill measures at birth, at the age of 3-18 months and at the age of 26-42 months with the magnitude of self-productivity. Third, we assess the returns on general and stage specific investments on child's skill measures at different stages. The skill and health indicators are derived from a comprehensive battery of maternal assessments. The first skill indicator is the birth weight. Empirical research summarized in (Reichman; 2005) suggests that the birth weight reflects some important skills and health dimensions 
for socio-economic outcomes in adolescence and adulthood. ${ }^{1}$

Our empirical findings indicate that both, acquired skills at previous stages and parental investments, contribute to the skill formation process in early childhood. The magnitude of self-productivity varies between skills and over time. A one percent increase in birth weight increases child's noncognitive skills and child's health between 0.34 and 0.64 percent until the age of 18 months. Until the age of 42 months a one percent increase of child's noncognitive skills at the second stage leads to an increase in child's verbal skills and child's everyday skills by 0.58 and 1.04 percent. The estimation results suggest strong synergies between child's health and child's noncognitive skills.

Furthermore, we find that father's support and mother's physical and mental health exert a positive influence on the child's noncognitive skill development, which deepens further skill formation through self-productivity. Families who pay attention to a regular interaction with their child and a regular meal significantly improve skill formation in early childhood. Our investigation may also be helpful for understanding the causality behind the intergenerational transmission of human capital and inequality that takes place in early childhood. The magnitude of self-productivity in the first three years of life suggests that strong compensatory effort is needed to improve skills and health for children from disadvantage families. In addition, improvements in nutrition for eliminating birth weight differences will be more effective if they are combined with following up parental investments.

The rest of the paper is organized as follows. In chapter 2 the skill production function and the concept of self-productivity are introduced with regard to the following empirical analysis. Section 3 describes the sample and the summary statistics, based on the GSOEP for the birth cohorts 2002-2005. Section 4 presents the estimation approach and discusses the empirical results. Section 5 concludes.

\footnotetext{
${ }^{1}$ According to Black et al. (2007) a ten percent increase in birth weight increases school success and wages by one percent, while according to Oreopoulos et al. (2006) an increase of the birth weight by 100 grammes increases school success by 0.5 percent.
} 


\section{Self-productivity in a three stage process}

For the empirical investigation of self-productivity a three stage skill formation process is specified, see Cunha and Heckman (2007). ${ }^{2}$ We investigate a child's skill development at birth, at the age of 3-18 months and at the age of 26-42 months (see Table 1). For each stage inputs and outcomes are discussed. ${ }^{3}$ Equation (1) presents the skill production function at birth. The birth weight, $S_{1}$, seems to be a reasonable predictor for the skill and health development in the short and even in the longer run (Oreopoulos et al.; 2006; Black et al.; 2007; Barker et al.; 2001). The birth equation (1) consists of two inputs: $S_{0}$ denotes initial characteristics of the newborn and $I_{1}$ denotes parental investment in the first stage

$$
S_{1}=f_{1}\left(S_{0}, I_{1}\right)
$$

Initial children's characteristics are the gender and the number of siblings (or twins) at birth. Investments can be stage specific or more general. Important stage specific investments are the health and the behavior of the mother during pregnancy (Barker; 1992). ${ }^{4}$ The educational status of the mother or their living environment can be regarded as general investment. ${ }^{5}$

For the skills at the second stage the GSOEP contains several indicators of the personality traits and health of the children. Mothers are asked to assess the satisfaction, crying behavior, console behavior, activity and the health of their newborn on a four point Likert Scale. The indicators will be interpreted as different aspects of the child's noncognitive skills and child's health, for instance (Borghans et al.; 2007)), which can be productive for the formation of cognitive, noncognitive skills and health at later stages. For instance, high activity enhances the child's movement which improves the development of motor and everyday skills. And poor health

\footnotetext{
${ }^{2}$ This technology of skill formation is based on an extension of the Ben-Porath model on investment over life cycle (Ben-Porath; 1967). Unlike the Ben-Porath model different types of investments, skills and technologies are allowed for each stage (Cunha and Heckman; 2007).

${ }^{3}$ For an introduction to the psychological literature on emotions, child-parental interaction and development, see Heckhausen and Heckhausen (2006); Holodynski (2005) among others.

${ }^{4}$ Information about mothers' physical and mental state three months before birth is used as a proxy for the fetal environment.

${ }^{5}$ For instance Chevalier and O'Sullivan (2007) find, in line with Currie and Moretti (2003) that one additional year of maternal education increases the average birth weight by 70 grammes. Higher returns to education are identified for mothers at the lower end of the educational range.
} 
Table 1: Stages and outcomes in early childhood

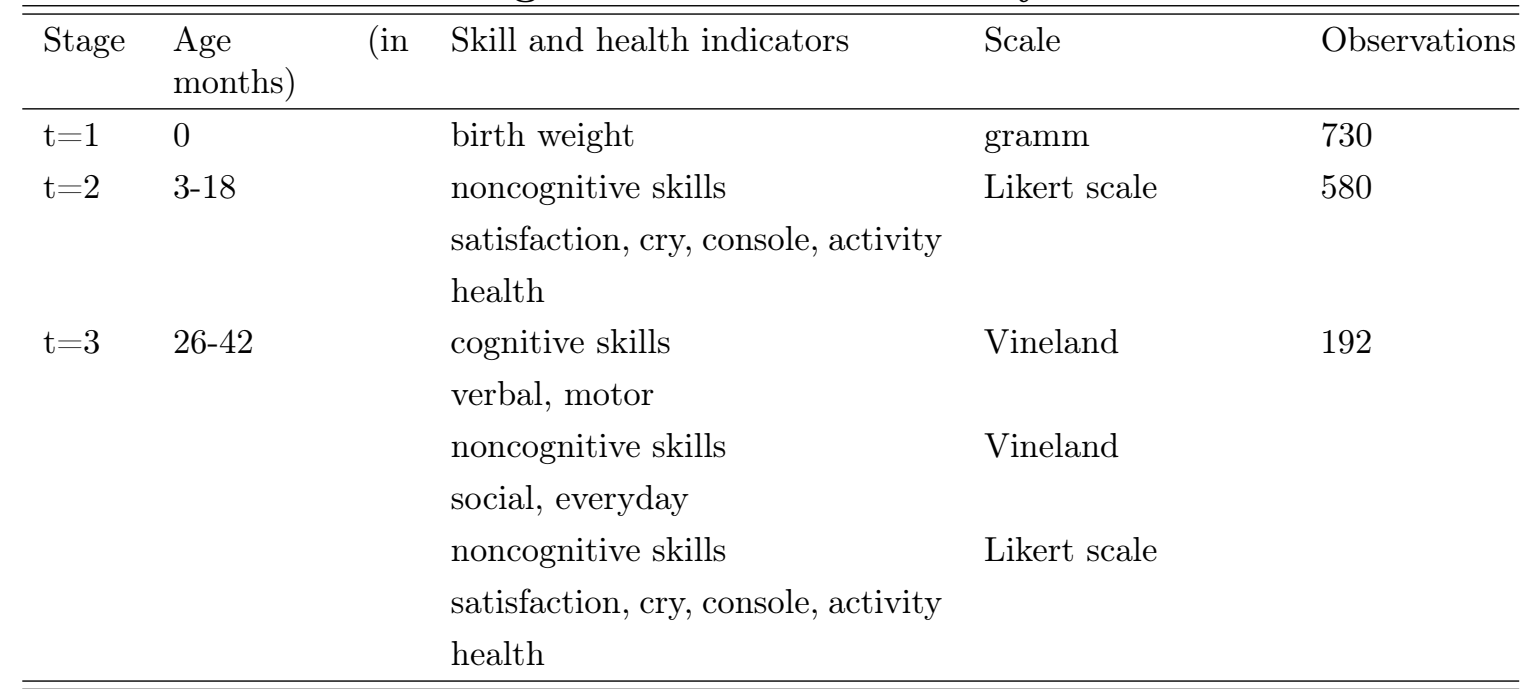

might reduce relation to other children, movements and satisfaction and therefore may hamper the acquisition of verbal, social and motor skills at later stages. In addition, we compute one overall skill indicator, called meta skill, which is the average of these five skill measures. According to the technology of skill formation each of these skill indicators is regarded as a function of current parental investments, $I_{2}$, and the skill indicator at birth, $S_{1}$, (see equation 2). The index j describes the five indicators of noncognitive skills and health $(\mathrm{j}=1, \ldots, 5)$ and the meta skill $(\mathrm{j}=6)$

$$
S_{2}^{j}=f_{2}\left(S_{1}, I_{2}\right) \quad \text { for } \quad j=1,2, \ldots, 6 \text {. }
$$

At this stage, a strong father's support in raising children represents a stage specific investment. There can be two channels through which father's support enhances the child's skills. First, each contact with the father could improve the father-child relationship and raise the child's satisfaction, activity, crying and console behavior (Gamble et al.; 2007; Laucht; 2005; Siantz and Smith; 1994). Second, it may reduce the stress of the mother which also improves the child's development. Furthermore, mothers' physical and mental health and children's nutrition between 3-18 months contribute to a child's skill development. Note that all of these skills at the second stage represent some dimensions of the child's noncognitive skills. Thus, we expect that each input might have different impacts on the child's skills.

For the analysis at the last stage, the data again contain mothers' assessments of four personality traits and their children's health. A meta skill is computed as the mean of these noncognitive skills and the health. In addition, the GSOEP contains 
a survey of child's progress in verbal, motor, social and everyday skills. The mothers are asked to assess these skills, based on the Vineland Adapted Behaviour Scale (Sparrow et al.; 1984). The scale includes five assessments for each, verbal, motor, social and everyday skills (see Table A2 in the Appendix). Verbal skills are one of the most important cognitive skills which are a prerequisite for the acquisition of other cognitive skills. The development of motor skills is closely related to other cognitive skills such as perception and verbal skills (Steigleider et al.; 2002). Everyday skills include cognitive and noncognitive components. Social skills can be regarded as noncognitive skills which are an important part of culture capital.

Altogether, we investigate the skill formation process of nine skill indicators and health at the third stage. Equation (3) represents the skill production function, where skills and health at the third stage $S_{3}^{i}$ depend on both current parental investments $I_{3}$ and on the cumulated skills and health from the previous stage $S_{2}$

$$
S_{3}^{i}=f_{3}\left(S_{2}^{j}, I_{3}\right) \quad \text { for } \quad i=1,2, \ldots, 10 \quad j=1,2, \ldots, 6
$$

$S_{2}^{j}$ denotes skills and health at the second stage and is the result of the skill level at the first stage and of investment at the second stage (see equation (2)). $I_{3}$ includes both, stage specific and general investments at the third stage. In some cases the mothers participate in the workforce. This could influence the development of skills, due to the fact that she relies on other types of child care such as childminder or institutional child care. In the case of institutional child care, children have contact to other children which influence their cognitive and noncognitive skills through peer effects, for instance (Magnuson et al.; 2007). Whether the influence is positive or not also depends on the quality of institutional child care, the type and frequencies of parents' activities and child's characteristics. The influence of differences in the socio-economic living conditions, measured by current municipality size or the availability of a garden, will be investigated for the skill formation process. Central for our analysis is the concept of self-productivity (equation (4)). Selfproductivity means that skills acquired at one stage foster skills advancement at later stages.

$$
\frac{\partial S_{t}^{i}}{\partial S_{t-1}^{j}}=\frac{\partial f_{t}\left(S_{t-1}^{i}, I_{t}\right)}{\partial S_{t-1}^{j}} \quad i=1,2, \ldots, 10 \quad j=1,2, \ldots, 6 \quad t=1,2,3
$$

Self-productivity may differ between different types of skills at different stages in the life cycle. 
Theoretically it is possible that only one of both inputs affects the skill production at a certain stage. Equation (5) describes the case where the skill production in $t$ is independent of skills in $(t-1)$. In this case, levels of skills in t result solely from levels of investments in t. Hence, compensating policies could have a large impact on skill development and there is no multiplier effect. Equation (6) describes the other polar case where the skill production is independent of investments. At each period the skill formation depends only on cumulative skills before, not on investments. Hence, compensatory policies have no impact at all, with the exception of those that are targeted to improve the starting conditions.

$$
\begin{gathered}
S_{t}=f_{t}\left(S_{t-1}, I_{t}\right)=f_{t}\left(I_{t}\right) \\
S_{t}=f_{t}\left(S_{t-1}, I_{t}\right)=f_{t}\left(S_{t-1}\right)
\end{gathered}
$$

The following sections introduce the data and investigates the impact of selfproductivity and parental investments in a three stage process.

\section{The data set and descriptive statistics}

\subsection{Data}

The German Socio-Economic Panel (GSOEP) is a representative national longitudinal data set which surveys households and individuals beginning in 1984 (HaiskenDeNew and Frick; 2005). It provides an informative data base with a rich set of indicators of children's cognitive and noncognitive skills at several stages in early childhood. Since 2003, detailed information on the birth of children have been integrated in the GSOEP by an extra "Mother-Child" questionnaire.

This questionnaire is addressed to all mothers who gave birth to a child in the current survey year or the year before. Thus the age of the child varies between 0 and 18 months. The first birth cohort we can observe is the birth cohort 2002. Further, we observe the birth cohorts 2003, 2004 and 2005. The questionnaire contains detailed information about the pregnancy, the body measurement and the health of the child after birth. In the year 2005, the second "Mother- Child" questionnaire for 2-3 year old children was introduced. Thus, we observe the birth cohort of 2002 in 2005 repeatedly. The "Mother- Child questionnaire 2" contains detailed information about maternal valuations of various cognitive and noncognitive skills of the 26-42 years old children as well as information about parental experiences with their child. 
When excluding missing observations, the pooled sample amounts to 730 children born between 2002 and 2005. For the second stage the sample contains 580 children from 3-18 months. And the third sample consists of 192 children aged between two and three years from the birth cohort 2002 who's mothers have been successfully interviewed again in 2005 .

\subsection{Skill measurement and investment at birth}

Table 2 reports descriptive statistics for all mothers with newborns in at least one of the birth years 2002, 2003, 2004 and 2005. It contains means and standard deviations of variables for each birth cohort and for the pooled sample used in the estimation. Children's birth information such as weight, gender and year of birth are derived from the newborn questionnaire. Information about mothers' education, height, health, age and citizenship are derived from the personal questionnaire.

As a first skill indicator some functions of birth weight (birth weight, natural logarithm of birth weight, fetal growth and an indicator of normal birth weight) will be regarded in the econometric analysis (see Chapter 4). The distribution of birth weight by birth cohorts and in the pooled sample is presented in Figure 1. The average birth weight differs between 3324.21 gram and 3351.74 gram depending on the year of birth. Fetal growth, defined by birth weight per weeks of pregnancy is on average 85.31 and varies considerably. In accordance to the WHO classification, children born below 2500 grammes are assigned to low birth weight (OECD; 2004). The percentage of children with low birth weight varies around seven percent. ${ }^{6}$

Mothers with a lower socioeconomic status are at higher risk for low birth weight children (Reichman; 2005). ${ }^{7}$ The average number of years of mothers's education varies between 12.61 in 2002 and 12.84 in 2004/2005. Maternal health is measured

\footnotetext{
${ }^{6}$ Low birth weight is regarded as a serious risk factor for skill development (Steigleider et al.; 2002). The most common illness for children with low birth weight is cerebral palsy (Reichman; 2005). Incidentally, these children have a higher probability to suffer from breathing and deafness or even to go blind, in comparison to their counterpart with normal weight which again is a cause for further diseases such as asthma. The extent of health risks is higher, the lower the birth weight (Reichman; 2005). Currie and Hyerson (1999) show that low birth weight increases the probability of obesity and heart diseases in adulthood. These diseases again lead to inappropriate learning conditions for children at school age. Social costs of low birth weight are investigated by Almond et al. (2005).

${ }^{7}$ The intergenerational transmission of human capital varies between countries. For instance, estimates indicate that the transmission is lower in the Scandinavian countries and stronger in the United States (Solon; 1999).
} 
Table 2: Descriptive statistics at the first stage

\begin{tabular}{|c|c|c|c|c|}
\hline Variables & 2002 & 2003 & $2004 / 2005$ & pooled sample \\
\hline \multicolumn{5}{|l|}{ Skill indicator $S_{1}$} \\
\hline \multirow[t]{2}{*}{ birth weight (in grammes) } & 3331.03 & 3324.21 & 3351.74 & 3335.52 \\
\hline & $(565.27)$ & $(561.98)$ & $(561.30)$ & $(562.27)$ \\
\hline \multirow[t]{2}{*}{ ln (birth weight) } & 8.09 & 8.09 & 8.10 & 8.10 \\
\hline & $(0.19)$ & $(0.19)$ & $(0.19)$ & $(0.19)$ \\
\hline \multirow[t]{2}{*}{ fetal growth } & 85.18 & 84.86 & 85.55 & 85.31 \\
\hline & $(12.44)$ & $(12.81)$ & $(13.12)$ & $(12.78)$ \\
\hline \multirow[t]{2}{*}{$\mathrm{NBW}\left(>2500\right.$ grammes $^{a}$} & 0.93 & 0.93 & 0.94 & 0.93 \\
\hline & $(0.26)$ & $(0.25)$ & $(0.23)$ & $(0.25)$ \\
\hline \multicolumn{5}{|l|}{ Newborn's characteristics $S_{0}$} \\
\hline \multirow[t]{2}{*}{ Male } & 0.50 & 0.52 & 0.48 & 0.50 \\
\hline & $(0.50)$ & $(0.50)$ & $(0.50)$ & $(0.50)$ \\
\hline \multirow[t]{2}{*}{ No siblings } & 0.43 & 0.43 & 0.44 & 0.43 \\
\hline & $(0.50)$ & $(0.50)$ & $(0.50)$ & $(0.50)$ \\
\hline \multirow[t]{2}{*}{ Twins } & 0.02 & 0.03 & 0.03 & 0.03 \\
\hline & $(0.15)$ & $(0.18)$ & $(0.16)$ & $(0.16)$ \\
\hline \multicolumn{5}{|l|}{ Mother's "investment" $\left(I_{1}\right)$} \\
\hline \multirow[t]{2}{*}{ Good fetal environment } & 0.66 & 0.67 & 0.80 & 0.71 \\
\hline & $(0.47)$ & $(0.47)$ & $(0.40)$ & $(0.45)$ \\
\hline \multirow[t]{2}{*}{ Mother's height (in cm) } & 167.55 & 166.68 & 168.02 & 167.42 \\
\hline & $(6.43)$ & $(6.44)$ & $(5.61)$ & $(6.53)$ \\
\hline Mother's health & 6.71 & 6.58 & 5.61 & 6.31 \\
\hline (one year before birth) & $(6.78)$ & $(8.82)$ & $(7.31)$ & $(7.66)$ \\
\hline \multirow[t]{2}{*}{ Mother's age (in years) } & 29.93 & 30.50 & 31.21 & 30.54 \\
\hline & $(5.33)$ & $(5.52)$ & $(5.44)$ & $(5.44)$ \\
\hline \multirow[t]{2}{*}{ Mother's age square } & 961.36 & 923.88 & 960.34 & 1003.34 \\
\hline & $(334.98)$ & $(322.10)$ & $(342.11)$ & $(338.04)$ \\
\hline \multirow[t]{2}{*}{ Mother's education (in years) } & 12.61 & 12.65 & 12.84 & 12.70 \\
\hline & $(2.66)$ & $(2.77)$ & $(2.81)$ & $(2.74)$ \\
\hline \multirow[t]{2}{*}{ Mother German } & 0.86 & 0.90 & 0.92 & 0.89 \\
\hline & $(0.35)$ & $(0.30)$ & $(0.27)$ & $(0.31)$ \\
\hline \multirow[t]{2}{*}{ Municipality size } & 4.21 & 4.04 & 4.00 & 4.09 \\
\hline & $(1.91)$ & $(1.82)$ & $(1.82)$ & $(185)$ \\
\hline Observations & 258 & 236 & 236 & 730 \\
\hline
\end{tabular}

Data Source: Sample drawn from the GSOEP 2003-2005. Standard Deviations are in parentheses. Own calculation. a) Average weight in the group of NBW: 3446.33 grammes and in the group of LBW 2097.08 grammes. 
Figure 1: The distribution of birth weight

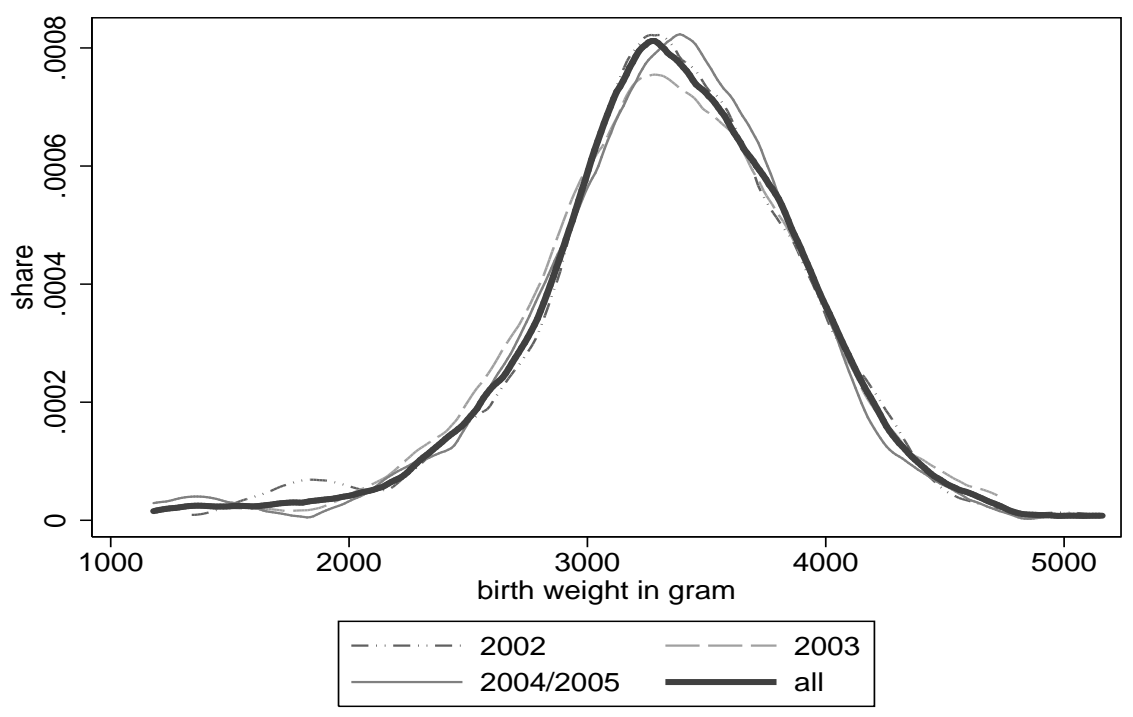

Data Source: Sample drawn from the GSOEP 2003-2005. Own calculation.

by the number of nights spend in hospital one year before pregnancy. On average mothers spend nearly one week in the hospital in the pooled sample. Mother's height is included as an indicator of some endowment factors, capturing some genetic elements. ${ }^{8}$ In the pooled sample the average height is $167.42 \mathrm{~cm}$.

Since we have only 43 percent first born children, the average age of the mother in nearly all columns is above 30 years. The risk of low birth weight children increases for very young mothers, meaning two years after menarche, and for mothers in the late thirties or older, for instance (Reichman; 2005). Mother's physical and mental constitution three months before birth are used as an indicator of intrauterine growth retardation. In the pooled sample, 71 percent of all mothers are in good physical and mental state before birth. Finally, the environmental factors during pregnancy might have an impact on birth weight, which is measured by the municipality size.

\subsection{Skill measurement and investment at the second stage}

The skill measurement at the second stage is based on maternal ratings. The mothers were asked five characteristics of their child in the newborn questionnaire. These questions are: "My child's health concerns me", "My child is generally happy and

\footnotetext{
${ }^{8}$ Lunde et al. (2007) find that maternal endowment factors, among them mother's height, explained 22 percent of the variation in birth weight.
} 
satisfied", "My child is easily irritated and cries frequently", "My child is difficult to console" and "My child is curious and active". The responding mothers could specify on the Likert Scale with four categories to what extend the statements apply: "Applies fully", "Applies more", "Applies less" and "Does not apply".9 The ordinal scales are transformed into a metric scale. We assign to each item on the Likert Scale numerical levels in percent, where 12.5 percent is the lowest value ("does not apply"), 37.5 percent, 62.5 percent and 87.5 percent ("Applies fully") the highest value. Each numerical level in percent is the mean between two categories. This transformation is based on the assumption that all respondents have the same metric scale in mind and value the meaning of each category with the same percentage (Praag; 1991). ${ }^{10}$ 97 percent of the mothers are the major care giver for their child which advances the quality of the skill indicators calculated from their ratings. We examine each of these four noncognitive skills and the health separately. Furthermore, the average of these five skill and health indicators is calculated to provide an overall skill indicator $\left(\frac{1}{j} \sum_{j=1}^{5} S_{j}\right)$.

Table 3 reports means and standard deviations of the variables for the pooled birth cohorts used in the estimation. ${ }^{11}$ In accordance to the technology of skill formation, Table 3 is divided in two parts. The upper part presents outcomes and the lower part presents inputs at this stage. The average value of each skill, as presented in Table 3, lies on the upper bound of scale. The lowest level is 72.03 percent (cry behavior) and the highest level is 82.37 percent (activity). Judged by the mother, the child's noncognitive skills at this stage are well developed. In particular, the child's activity and satisfaction attain the highest assessments. The scale of the meta skill variable varies between 32.5 and 87.5 percent.

The average birth weight, mother's height, mother's years of education and the municipality is nearly the same compared to the first stage for the pooled sample. ${ }^{12}$ The percentage of mothers who feel very strongly supported by the father is about

\footnotetext{
${ }^{9}$ We adjust the scale of these five assessments in order to provide an uniform scale for all indicators. For all assessments it is essential that the higher the value of the scale the better is the outcome.

${ }^{10}$ Let $S_{k}$ denote the latent continuous scale which ranges from $[0,100]$. With four answer categories $(\mathrm{k}=1,2 \ldots, \mathrm{K})$ the transformation into a metric scale based on the assumption of equal interval length between two categories: $S_{k}=(2 k-1) * \frac{100}{2 K}$. This assumption is a reasonable approximation of respondents replies (Praag; 1991).

${ }^{11}$ The sample size decreases by 118 observations due to the fact that all children younger than three month are excluded. Additionally, we drop 32 observations due to missing values.

${ }^{12}$ So the reduction of the sample has no systematic consequence for the reported means.
} 
Table 3: Descriptive statistics at the second stage (pooled sample)

\begin{tabular}{|c|c|c|c|c|}
\hline Variables & Mean & $\begin{array}{l}\text { Standard devia- } \\
\text { tion }\end{array}$ & Minimum & Maximum \\
\hline \multicolumn{5}{|l|}{ Skill indicators $S_{2}$} \\
\hline Health & 72.85 & 19.01 & 12.5 & 87.5 \\
\hline Satisfaction & 80.69 & 12.77 & 12.5 & 87.5 \\
\hline Cry behavior & 72.03 & 16.71 & 12.5 & 87.5 \\
\hline Console & 77.59 & 14.57 & 12.5 & 87.5 \\
\hline Activity & 82.37 & 11.12 & 12.5 & 87.5 \\
\hline Meta skill & 77.10 & 9.52 & 32.5 & 87.5 \\
\hline \multicolumn{5}{|l|}{ Skill indicators $S_{1}$} \\
\hline Birth weight & 3336.64 & 553.57 & 1230 & 5160 \\
\hline $\ln$ (birth weight) & 8.10 & 0.18 & 7.11 & 8.55 \\
\hline \multicolumn{5}{|c|}{ Child's characteristics $(t=2)$} \\
\hline Male (in \%) & 0.49 & 0.50 & 0 & 1 \\
\hline Child's age (in month) & 8.04 & 3.32 & 3 & 18 \\
\hline No siblings & 0.46 & 0.50 & 0 & 1 \\
\hline \multicolumn{5}{|l|}{ Mother's "investments" $I_{2}$} \\
\hline Strong father's support & 0.29 & 0.45 & 0 & 1 \\
\hline Good post fetal environment & 0.74 & 0.44 & 0 & 1 \\
\hline Mother's height (in cm) & 167.44 & 6.71 & 145 & 189 \\
\hline Mother's education & 12.77 & 2.77 & 7 & 18 \\
\hline Mother German & 0.90 & 0.30 & 0 & 1 \\
\hline Regular Meal & 0.89 & 0.31 & 0 & 1 \\
\hline Garden & 0.69 & 0.46 & 0 & 1 \\
\hline Municipality size & 4.11 & 1.87 & 1 & 7 \\
\hline Observations & & & & 580 \\
\hline
\end{tabular}

Data Source: Sample drawn from the GSOEP 2003-2005. Own calculation.

30 percent. 25 percent of all mothers are in poor post fetal environment, meaning that three months after birth they feel in bad physical and mental state. 89 percent of all included families eat a meal with meat, fowl or fish, at least twice a week. Nearly 70 percent of all families with newborns have a garden. ${ }^{13}$ In the second stage we control for child's age in months, because skill measures in one month can differ

\footnotetext{
${ }^{13}$ Both measures, meal and the availability of a garden, reflect central aspects of the socioeconomic status of the family. A continuous measure of permanent household income was never significant. This measure is highly correlated with mother's education and was therefore excluded from estimation.
} 
from skill measures at any other month. ${ }^{14}$ The average age of the children in the second stage is 8.04 months. It varies between 3 and 18 months.

\subsection{Skill measurement and investments at the third stage}

Skill outcomes in 2005, when children are 26-42 months old, are calculated from maternal ratings. Besides a child's noncognitive skills and health (see Appendix Table A2), stage specific assessments on verbal, motor, social and everyday skills are available. The mothers were asked what new things her child has learned. They could answer on Vineland Adopted Behaviour scale, "yes" my child has learned this thing, "to some extent" my child has learned this thing and "no" my child has not learned this thing. ${ }^{15}$ We add the five values of each assessment within competence group to construct an aggregate measure for verbal, motor, social and everyday skills. The sum of scales ranges from 5 to 20. In order to adjust the scale of skills based on Vineland Scale to the scale of skills based on the Likert Scale, we multiply by the factor four. The scale ranges now from 20-80 percent (see Appendix Table A3).

Table 4 is divided in two parts. The upper part reports means and standard deviations of children's outcomes at this stage, the lower part reports means and standard deviations of all previous skills and current investments. The levels of skills vary significantly between verbal, motor, social and everyday skills. While the average level of verbal skills is about 71.56 percent, the average level of everyday skills is 17.89 percentage points lower. The high development of verbal skills in comparison to motor, social and everyday skills is a consequence of the early beginning of verbal competencies. Between 10 and 18 months children begin to speak. After the 18th month, children attain a vocabulary tool of more than 50 words (Tracy; 2000). Furthermore, the acquisition of verbal skills is also possible for children with diminished other cognitive skills (Grimm; 1999).

The average level of all noncognitive skill indicators are rather similar to the second stage. In particular, child's satisfaction and activity behavior are well developed

\footnotetext{
${ }^{14}$ The older the child the higher is the value of specific noncognitive skills. For the cry behavior we expect a reverse correlation.

${ }^{15}$ These skills partly stem from assessments of the German U7 examination. After the birth, parents receives a child examination book for medical check-up. The German U7 examination is one of the medical check-ups in early childhood which takes place between 21 and 24 months.
} 
Table 4: Descriptive statistics at the third stage

\begin{tabular}{|c|c|c|c|c|}
\hline Variables & Mean & $\begin{array}{l}\text { Standard devia- } \\
\text { tion }\end{array}$ & Minimum & Maximum \\
\hline \multicolumn{5}{|l|}{ Skill indicators $S_{3}$} \\
\hline \multicolumn{5}{|c|}{ based on Vineland Scale } \\
\hline Verbal & 71.56 & 10.73 & 32 & 80 \\
\hline Motor & 68.00 & 11.07 & 20 & 80 \\
\hline Social & 70.48 & 10.46 & 36 & 80 \\
\hline Everyday & 53.67 & 15.93 & 20 & 80 \\
\hline \multicolumn{5}{|c|}{ based on Likert Scale } \\
\hline Health & 73.83 & 20.27 & 12.5 & 87.5 \\
\hline Satisfaction & 81.51 & 11.00 & 37.5 & 87.5 \\
\hline Cry behavior & 68.23 & 16.57 & 12.5 & 87.5 \\
\hline Console & 74.87 & 15.13 & 12.5 & 87.5 \\
\hline Activity & 77.34 & 20.17 & 37.5 & 87.5 \\
\hline Meta skill $(\mathrm{t}=3)$ & 75.16 & 9.50 & 37.5 & 87.5 \\
\hline \multicolumn{5}{|l|}{ Skill indicator $S_{2}$} \\
\hline Meta skill $(\mathrm{t}=2)$ & 77.53 & 8.52 & 52.5 & 87.5 \\
\hline \multicolumn{5}{|l|}{ Skill indicator $S_{1}$} \\
\hline Birth weight & 3362.01 & 536.86 & 1340 & 5160 \\
\hline ln (birth weight) & 8.11 & 0.18 & 7.20 & 8.55 \\
\hline \multicolumn{5}{|c|}{ Child's characteristics $(t=3)$} \\
\hline Male (in\%) & 0.50 & 0.50 & 0 & 1 \\
\hline Child's age (in month) & 33.60 & 3.64 & 26 & 42 \\
\hline No Siblings & 0.35 & 0.52 & 0 & 1 \\
\hline \multicolumn{5}{|l|}{ Mother's "investments" $I_{3}$} \\
\hline Institutional care (h/week) & 7.89 & 12.89 & 0 & 45 \\
\hline Parental activity & 26.47 & 4.14 & 9 & 35 \\
\hline Speak German to child & 0.82 & 0.38 & 0 & 1 \\
\hline Mother's height & 167.57 & 6.25 & 154 & 182 \\
\hline Mother's education & 12.76 & 2.76 & 7 & 18 \\
\hline Mother German & 0.89 & 0.32 & 0 & 1 \\
\hline Work hour mother & 5.08 & 11.63 & 0 & 56 \\
\hline Regular meal & 0.90 & 0.30 & 0 & 1 \\
\hline Garden & 0.75 & 0.43 & 0 & 1 \\
\hline Municipality size & 4.02 & 1.84 & 1 & 7 \\
\hline Observations & & & & 192 \\
\hline
\end{tabular}

Data Source: Sample drawn from the GSOEP 2003-2005. Own calculation. 
at the third stage. At the bottom of Table 4, descriptive statistics for general and stage specific investments and control variables used in the estimation are presented. Among the 2-3 year old children, the labor market participation of the mothers differs between no labor market participation and more than 40 hours per week. Mother's work on average five hours. The percentage of mothers who do not work at all is about $76.6 \%$. Since the decision to work affects the decision of extra domestic child care, we find a similar pattern for the institutional child care participation. A small fraction of children attends the kindergarten at least for a half day (22.92 percent) while 62.50 percent do not attend the kindergarten at all. Since the extension of the provision of institutional child care is currently on the top of the political agenda in Germany, we investigate the effect of institutional child care on child's skill development in the econometric part.

Additionally, a stage specific investment variable is created, called parental activity, based on nine questions derived from the mother- child (2) questionnaires. The mothers were asked how often (in days) they are singing, watching TV, going to the playground and some other activities. ${ }^{16}$ Mothers reply how frequently each investment has been undertaken in the past weeks ( $1=$ never, $4=$ everyday). The sum of these nine questions provides a total score of parental activities (see Appendix Table A4). The scale of parental activities ranges from 9-35, with an average value 26.34. At the third stage the percentage of children growing up with solely German speaking parents is about 83 percent. The average values for mother's height, mother's years of education and for municipality are nearly the same as in the pooled sample at the stages before. In our sample 75 percent of all families have a garden. The share of children without siblings decreases by 21 percent points in comparison to the second stage. Child's age varies between 26-42 months and the average age is about 33.60 months.

\footnotetext{
${ }^{16}$ Watching television or video together with the parents might have a positive impact if parents choose appropriate telecasts or videos for their children.
} 


\section{Econometric analysis}

\subsection{Birth outcome estimation}

Our basic estimation equation at birth (equation (7)) is a linear representation of the skill production function described in section 2 , where $S_{1}^{j}$ denotes the first skill indicator, $I_{1}$ denotes parental investments in $t=1$ and $S_{0}$ denotes the child's birth characteristics. Three different continuous variants of birth weight are investigated: birth weight, $\ln$ (birth weight) and fetal growth. The resulting $R^{2}$ statistics from the first stage regression with each variant of birth weight indicates that the $\ln$ (birth weight) provides the best fit (see Appendix Table A5). Thus, the natural logarithm of birth weight is used throughout the following discussion. Furthermore, a probit model has been estimated for the binary variable NBW.

$$
\underbrace{S_{1}^{j}}_{S_{1}}=\underbrace{\beta_{0}+\beta_{1} x_{1}+\beta_{2} x_{2}+\cdots+\beta_{k} x_{k}}_{I_{1}}+\underbrace{\gamma_{1} y_{1}+\gamma_{2} y_{2}+\gamma_{3} y_{3}}_{S_{0}}+u_{1}
$$

Table 5 reports the regression results, for all birth cohorts separately and for the pooled sample. ${ }^{17}$ The estimated coefficients are similar for all birth cohort regressions. Boys are significantly heavier than girls at birth (4 percent). The first born child is on average 0.05 percent lighter and twins are on average 30 percent lighter than normal births. So our findings are in line with the literature, confirming for instance that twins are at higher risk to be born with low birth weight (LBW) (Black et al.; 2007). Mothers' height and good health has a significant positive influence on the birth weight (Case et al.; 2005). However, in contrast to Currie and Moretti (2003); Chevalier and O'Sullivan (2007) we find no effect of maternal education on birth outcome. Presumably as a result of the small sample size the non-linear age effect is not strongly determined. For mother's nationality and the municipality size the estimates differ between birth cohorts and are mostly insignificant. The probit analysis, see Table A5 confirms the other regression results with one difference. Here, we find no significant gender difference in the probability to be born with normal compared to low birth weight.

\footnotetext{
${ }^{17}$ For the pooled sample we additionally control for cohort effects.
} 
Table 5: Determinants of $\ln ($ birth weight): first stage

\begin{tabular}{|c|c|c|c|c|}
\hline & 2002 & 2003 & $2004 / 2005$ & Pooled Sample \\
\hline \multicolumn{5}{|c|}{ Newborn's characteristics $S_{0}$} \\
\hline \multirow[t]{2}{*}{ Male } & $0.05^{* *}$ & 0.03 & $0.06^{* *}$ & $0.04^{* * *}$ \\
\hline & $(0.02)$ & $(0.02)$ & $(0.02)$ & $(0.01)$ \\
\hline \multirow[t]{2}{*}{ No Sibling } & $-0.05^{* *}$ & $-0.05^{* *}$ & -0.03 & $-0.05^{* * *}$ \\
\hline & $(0.02)$ & $(0.02)$ & $(0.03)$ & $(0.01)$ \\
\hline \multirow[t]{2}{*}{ Twin } & $-0.29 * * *$ & $-0.33^{* * *}$ & $-0.31^{* * *}$ & $-0.32^{* * *}$ \\
\hline & $(0.07)$ & $(0.06)$ & $(0.07)$ & $(0.04)$ \\
\hline \multicolumn{5}{|c|}{ Mother's "investments" $I_{1}$} \\
\hline \multirow[t]{2}{*}{ Mother's height } & $0.005^{* * *}$ & $0.006^{* * *}$ & $0.005^{* * *}$ & $0.005^{* * *}$ \\
\hline & $(0.002)$ & $(0.002)$ & $(0.001)$ & $(0.001)$ \\
\hline \multirow[t]{2}{*}{ Mother's health } & $-0.005^{* * *}$ & $-0.005^{* * *}$ & $-0.007^{* * *}$ & $-0.006^{* * *}$ \\
\hline & $(0.002)$ & $(0.001)$ & $(0.002)$ & $(0.001)$ \\
\hline \multirow[t]{2}{*}{ Fetal Environment } & -0.02 & $0.04^{*}$ & 0.01 & 0.005 \\
\hline & $(0.02)$ & $(0.02)$ & $(0.03)$ & $(0.01)$ \\
\hline \multirow[t]{2}{*}{ Mother's age } & $-0.03^{*}$ & -0.02 & 0.007 & -0.01 \\
\hline & $(0.018)$ & $(0.02)$ & $(0.02)$ & $(0.01)$ \\
\hline \multirow[t]{2}{*}{ Mother's age squared } & $0.001^{*}$ & 0.00 & -0.00 & 0.00 \\
\hline & $(0.0003)$ & $(0.002)$ & $(0.000)$ & $(0.0001)$ \\
\hline \multirow[t]{2}{*}{ Mother's education } & 0.003 & -0.007 & 0.005 & 0.001 \\
\hline & $(0.005)$ & $(0.0005)$ & $(0.004)$ & $(0.002)$ \\
\hline \multirow[t]{2}{*}{ Mother German } & $-0.05^{*}$ & -0.009 & 0.07 & -0.01 \\
\hline & $(0.03)$ & $(0.04)$ & $(0.04)$ & $(0.02)$ \\
\hline \multirow[t]{2}{*}{ Municipality size } & $-0.02^{* * *}$ & 0.004 & $0.01^{* *}$ & -0.0001 \\
\hline & $(0.006)$ & $(0.006)$ & $(0.006)$ & $(0.003)$ \\
\hline \multirow[t]{2}{*}{ Constant } & $7.76^{* * *}$ & $7.56^{* * *}$ & $7.07^{* * *}$ & $7.50^{* * *}$ \\
\hline & $(0.40)$ & $(0.42)$ & $(0.44)$ & $(0.24)$ \\
\hline F-test & $6.33^{* * *}$ & $6.29 * * *$ & $6.15^{* * *}$ & $16.22^{* * *}$ \\
\hline Adjusted $R^{2}$ & 0.1858 & 0.1984 & 0.1943 & 0.1868 \\
\hline Observations & 258 & 236 & 236 & 730 \\
\hline
\end{tabular}

Data Source: Sample drawn from the GSOEP 2003-2005. Standard Errors are in parentheses: *** significant at $1 \%$ level; **significant at $5 \%$ level; * significant at $10 \%$ level. Own calculation.

\subsection{Self-productivity between birth and 3-18 months}

The estimates of self-productivity are derived from equation (8), where $S_{2}^{j}$ denotes the indicators of noncognitive skills, the health and the meta skill at the second stage $j=1,2, \cdots, 6 . I_{2}$ denotes parental investments and $S_{1}$ represents our preferred skill 
indicator at birth (ln (birth weight)).

$$
\underbrace{S_{2}^{j}}_{S_{2}}=\underbrace{\delta_{0}+\delta_{1} x_{12}+\delta_{2} x_{22}+\cdots+\delta_{k} x_{k 2}}_{I_{2}}+\alpha_{1} S_{1}+u_{2} \quad \text { for } \quad j=1,2, \ldots, 6
$$

The parameter of interest $\alpha_{1}$ is estimated with ordinary least square (OLS) and two stage least square (2SLS). OLS estimates may suffer from omitted variables problems. For instance, it is not actual birth weight that matters for self-productivity. Instead observed and unobserved factors related to birth weight contribute to selfproductivity and further skill formation. Therefore, we use the variables at the first stage (equation (7)) to instrument the birth weight. For all models presented in Table 5 the associated p-values of the F-test indicates that the null hypothesis can be rejected at the $1 \%$ level. A Sargan's test of overidentifying restrictions indicates that the excluded variables twins, mother's health and mother's age satisfy the orthogonality condition $(\operatorname{cov}(u, z)=0) .{ }^{18}$

The 2SLS estimation results are presented in Table 6, the OLS results in Table A6 in the Appendix. Column 1 reports the estimates for the health and column 2-6 report the estimates for the five skill indicators.

Overall we find evidence for self-productivity. Controlling for maternal education, stage specific investments and environmental factors, our findings suggest that children who have experienced poorer skills at birth have significant lower skills at this stage. The results indicate that self-productivity differ between the skill indicators. The coefficient for the meta skill is 25.83. Since the natural logarithm of birth weight is used, the value implies that a reduplication of birth weight increases the meta skill by 25.83. Furthermore, Table 6 reports the coefficient of the dummy variable for birth weight $>2500$ gram instead of the $\ln$ (birth weight) specification. The coefficient in the binary specification is 18.73. This implies that having a birth weight higher than 2,500 grams enhances skills by 18.73. These two coefficients are very similar. Further estimates in the subsample of LBW (which are not reported in detail) suggest that self-productivity is continuously related with birth weight and therefore the discussion will refer to the continuous case. To compare the magnitude of self-productivity for the different skills, Table 6 contains the elasticity of self-productivity, evaluated at the sample mean, for the $\ln$ (birth weight), the normal

\footnotetext{
${ }^{18}$ For all models presented in Table 6 , the null hypothesis of overidentifying restrictions cannot be rejected at the 1 or 5 percent level.
} 
Table 6: 2SLS results for self-productivity and investment, Likert Scale

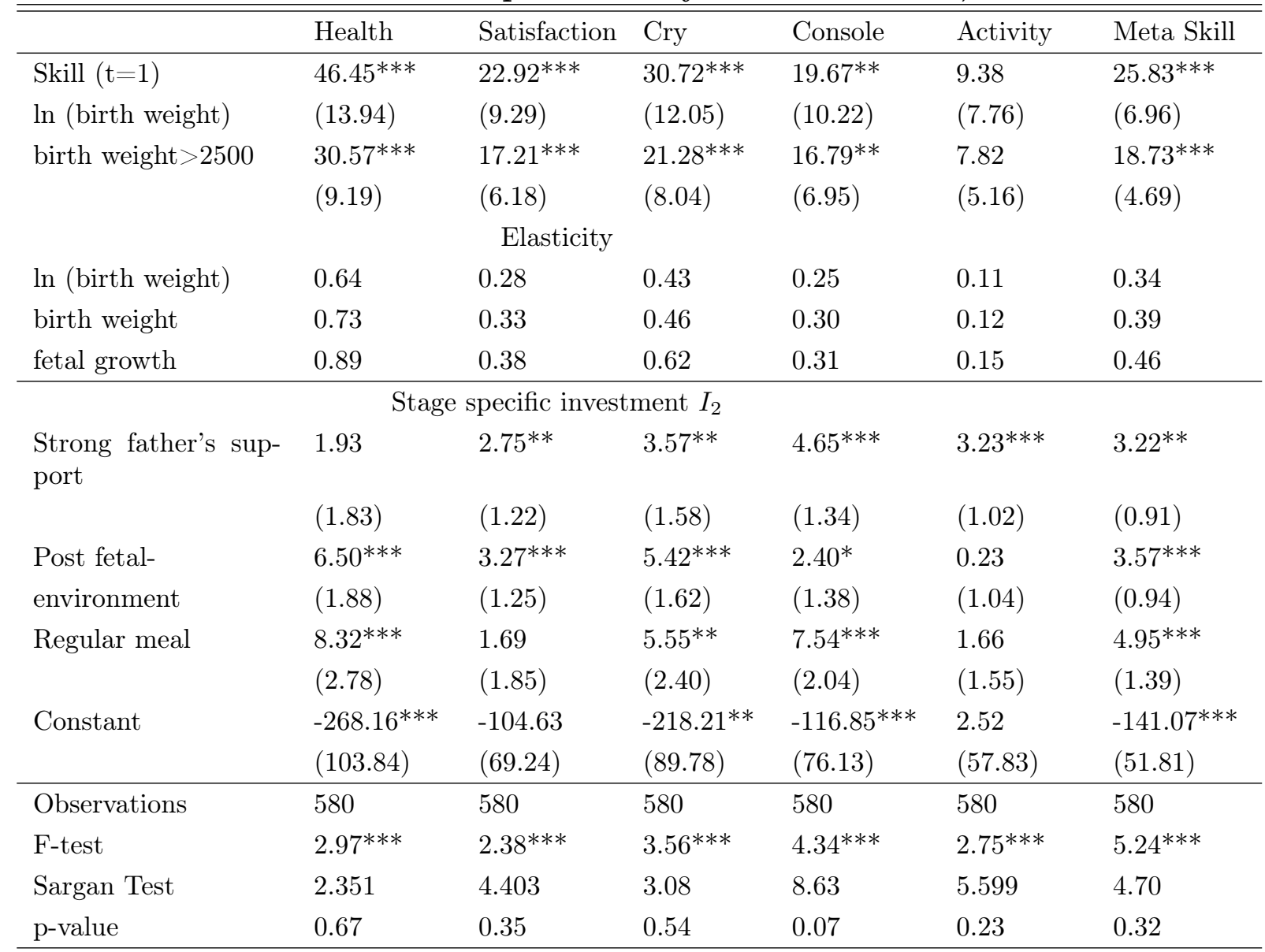

Data Source: Sample drawn from the GSOEP 2003-2005. Standard Errors are in parentheses: All models include child's gender, child's age, siblings, mother's height, mother's education, mother's nationality, availability of a garden and municipality size. $* * *$ significant at $1 \%$ level; ** significant at $5 \%$ level; ${ }^{*}$ significant at $10 \%$ level. Own calculation.

birth weight and for fetal growth. The elasticity for the meta skill between birth and the second stage is 0.34 . The elasticities varies between 0.64 for child's health and 0.11 for child's activity (the latter is not different from zero). The elasticities for birth weight and fetal growth are slightly higher compared to $\ln$ (birth weight) for each of the indicators, confirming evidence for self-productivity. The OLS estimates of equation (8) (Table A6 in the Appendix), are significantly lower. This downward bias in the estimates results from an omitted variables problem. The 2SLQ estimates of self-productivity are therefore more reliable than the OLS estimates.

Investment also matter. A strong support of the father, mother's good mental and physical state three month after birth and the availability of a warm meal with meat, fowl or fish, at least twice a week, foster the formation of child's noncognitive skills and health at the age between 3-18 months. These results confirm that 
the early father-child interaction fosters emotional security and resilience and may even compensate the risk of low birth outcomes (Barker et al.; 2000; Laucht; 2005). The coefficients of birth weight on child's noncognitive skills (self-productivity) is roughly eight times larger than the one of paternal support on child's noncognitive skills. However one has to keep in mind that for skill formation over the life cycle father's support gains relevance due to self-productivity. These findings suggest that for fostering human capital more attention should be paid to the quality of early parent-child interaction. This includes both, emotion and nutrition. Both factors contribute to the intergenerational transmission of inequality and human capital.

Gender differences are significant for child's health, satisfaction and crying behavior. For these indicators, girls seem to have higher skills than boys. For child's satisfaction and child's activity we find that both skills are more pronounced the older the child is. We tested whether the age results depends on the sample chosen. Each sample was spilt into two subsamples, one for the 3-12 month olds and one for the 6-18 months olds. Table A7 (Appendix) reports our main parameter of interest for the two samples and the overall sample. Self-productivity remains important for both subsamples and is slightly higher for the sample with the older children.

\subsection{Self-productivity between 3-18 months and 26-42 months}

The estimates of self-productivity between the skills at the second stage and the skills at the third stage based on equation(9).

$$
\underbrace{S_{3}^{j}}_{S_{3}}=\underbrace{\phi_{0}+\phi_{1} x_{13}+\phi_{2} x_{23}+\cdots+\phi_{k} x_{k 3}}_{I_{3}}+\alpha_{2} S_{2}+u_{3} \quad \text { for } \quad j=1,2, \ldots, 10
$$

$S_{3}^{i}$ denotes a child's verbal, motor, social, everyday skills, child's personality traits and child's health at the third stage. $I_{3}$ denotes current parental investments and $S_{2}$ denotes the infant skill indicators from the previous period. Our primary parameter of interest is $\alpha_{2}$, which measures self-productivity. $\alpha_{2}$ is estimated with ordinary least square (OLS) and three stage least square (3SLS). In oder to take into account that a insufficient consideration of unobserved variables leads to a bias in the OLS estimates, we use an instrumental variable approach. The first stage equation (7) is used to instrument the birth weight and equation (8) for instrumenting the skills at the second stage. For the models presented in Table 6 the null hypothesis that all instruments are jointly insignificant can be rejected at the one percent level. At the third stage we excluded the variables father's support and post-fetal environment 
from the regression, because the Sargan-test indicates that they are uncorrelated with the error term of equation (9).

Table 7 reports the 3SLS estimation results for verbal, motor, social and everyday skills. It also contains the elasticities evaluated at the sample mean for all variants of birth weight. Self-productivity is evident in skill formation process between stage two and stage three. Higher noncognitive skills at the second stage lead to higher cognitive and noncognitive skills at the third stage. Thus the returns on higher birth weight and early parental investments accumulate further through self-productivity until the end of early childhood. Altogether, the magnitude of self-productivity is higher at the third stage in comparison to the second stage (see the chapter before). Self-productivity is larger for child's everyday skills (1.04 percent) and lower for a child's motor skills (0.50 percent). The estimates of equation (9) are very similar between the three specification of the birth weight, which confirms the relevance of self-productivity.

OLS results of equation (9) that do not account for omitted variables are documented in Table A8. OLS underestimates the magnitude of self-productivity.

Table 8 presents the 3SLS estimation results for the noncognitive skills and health (column 1-5) and for the meta skill (column 6). A one percent increase in the meta skill at the second stage leads to a 0.32 percent increase in the meta skill at the third stage. At this stage the elasticity is highest for child's console behavior (0.67) and child's activity (0.86). An active and inquiring personality is a stable characteristic at least within early childhood. ${ }^{19}$ At this stage self-productivity for the health and satisfaction is lower in comparison to the second stage (and statistically not different from zero). However, results in Table 8 suggest strong synergies between child's health in stage two and child's activities in stage three ( 0.71 percent) and between the past crying behavior and current activities (0.82). OLS results are documented in Table A9. OLS estimates of equation (9) that do not account for omitted variables lead to an underestimating of self-productivity.

Besides cumulative skills investment contribute to the skill formation process at the third stage. Mother's education enhances her child's verbal skills, activity and the meta skill, which is in line with Black et al. (2005). A one percent increase of years of education lead to an 0.10 increase of her child's verbal skill. Mother's education

\footnotetext{
${ }^{19}$ This result is in line with research findings on the Attention Deficit Hyperactivity Disorder (ADHD)(Currie and Stable; 2004).
} 
Table 7: 3SLS results for self-productivity and investment, Vineland Scale

\begin{tabular}{lllll}
\hline \hline & $\begin{array}{l}\text { Verbal } \\
(\text { cognitive })\end{array}$ & $\begin{array}{l}\text { Motor } \\
(\text { cognitive) }\end{array}$ & $\begin{array}{l}\text { Social } \\
\text { (noncognitive) }\end{array}$ & $\begin{array}{l}\text { Everyday } \\
\text { (noncognitive) }\end{array}$ \\
\hline Meta Skill $(\mathrm{t}=2)$ & $0.54^{* * *}$ & $0.44^{* *}$ & $0.63^{* * *}$ & $0.72^{* *}$ \\
& $(0.21)$ & $(0.22)$ & $(0.21)$ & $(0.33)$ \\
birth weight $>2500$ & $0.48^{* *}$ & $0.39^{*}$ & $0.58^{* * *}$ & $0.67^{* *}$ \\
& $(0.21)$ & $(0.22)$ & $(0.22)$ & $(0.34)$ \\
ln (birth weight) & \multicolumn{2}{c}{ Elasticity } & & \\
ln (LBW) & 0.58 & 0.50 & 0.69 & 1.04 \\
birth weight & 0.61 & 0.52 & 0.69 & 1.14 \\
fetal growth & 0.58 & 0.50 & 0.70 & 1.04 \\
\hline & 0.58 & 0.58 & 0.69 & 1.24 \\
Mother's education & $0.58^{* *}$ & 0.48 & 0.28 & -0.11 \\
Institutional care & $(0.29)$ & $(0.30)$ & $(0.29)$ & $(0.45)$ \\
Parental activity & 0.03 & 0.04 & $0.14^{* *}$ & $0.18^{*}$ \\
& $(0.06)$ & $(0.06)$ & $(0.06)$ & $(0.09)$ \\
Garden & $0.69^{* * *}$ & 0.21 & $0.38^{* *}$ & $0.45^{*}$ \\
Constant & $(0.17)$ & $(0.18)$ & $(0.17)$ & $(0.27)$ \\
& $4.67^{* * *}$ & $4.84^{* * *}$ & $5.72^{* * *}$ & 2.38 \\
\hline Observations & $(1.82)$ & $(1.92)$ & $(1.87)$ & $(2.90)$ \\
Sargan Test & -4.28 & -0.09 & 21.69 & -23.38 \\
P-vaule & $(22.22)$ & $(23.39)$ & $(22.68)$ & $(35.25)$ \\
\hline Data Sol and stage specific investment $I_{3}$ & 192 \\
& 192 & 192 & 192 & 1.544 \\
& 3.906 & 1.592 & 3.451 & 0.90788 \\
\hline
\end{tabular}

Data Source: Sample drawn from the GSOEP 2003-2005. Standard Errors are in parentheses: All models include child's gender, child's age, siblings, mother's height, mother's working hours, mother's nationality, regular meal, speak German with the child, parents married and municipality size. ${ }^{* *}$ significant at $1 \%$ level; ${ }^{* *}$ significant at $5 \%$ level; ${ }^{*}$ significant at $10 \%$ level. Own calculation.

has no measurable effect on child's social and everyday skills within early childhood. Similar there is no measurable influence on infant skill formation through mother's workforce participation at this stage. Mother's decision to work is often a decision of attending extra domestic child care such as institutional child care. The results reported in Table 7 show a significantly positive association between social and everyday skills and institutional child care in early childhood. Institutional child care however seems to have no influence on the development of a child's cognitive skills and have a negative impact on the development of the child's personality traits. There is a weak negative association between institutional care and a child's crying behavior which can result from a new introduction to the kindergarten, where chil- 
Table 8: 3SLS results for self-productivity and investment, Likert Scale

\begin{tabular}{lllllll}
\hline \hline & Health & Satisfaction & Cry & Console & Activity & Meta Skill \\
\hline Health $(\mathrm{t}=2)$ & 0.33 & 0.05 & $-0.50^{*}$ & 0.23 & $0.71^{* *}$ & 0.16 \\
Satisfaction $(\mathrm{t}=2)$ & $(0.30)$ & $(0.17)$ & $(0.29)$ & $(0.23)$ & $(0.33)$ & $(0.14)$ \\
& -0.63 & 0.11 & 0.30 & $0.94^{* * *}$ & $2.12^{* * *}$ & $0.56^{* * *}$ \\
Cry $(\mathrm{t}=2)$ & $(0.42)$ & $(0.21)$ & $(0.34)$ & $(0.30)$ & $(0.42)$ & $(0.19)$ \\
& 0.14 & -0.12 & $-0.44^{*}$ & 0.09 & $0.82^{* * *}$ & 0.10 \\
Console (t=2) & $(0.29)$ & $(0.15)$ & $(0.25)$ & $(0.21)$ & $(0.29)$ & $(0.13)$ \\
& -0.43 & 0.06 & 0.19 & $0.67^{* * *}$ & $0.96^{* * *}$ & $0.29^{*}$ \\
Activity (t=2) & $(0.33)$ & $(0.17)$ & $(0.27)$ & $(0.23)$ & $(0.33)$ & $(0.15)$ \\
& 0.18 & -0.09 & 0.15 & -0.27 & $0.81^{* *}$ & 0.16 \\
Meta skill (t=2) & $(0.36)$ & $(0.19)$ & $(0.30)$ & $(0.27)$ & $(0.35)$ & $(0.16)$ \\
& -0.12 & -0.04 & -0.27 & 0.45 & $1.59^{* * *}$ & $0.32^{*}$ \\
ln (birth weight) & $(0.44)$ & $(0.23)$ & $(0.36)$ & $(0.31)$ & $(0.43)$ & $(0.19)$ \\
ln (LBW) & 0.33 & Elasticity & & & & 0.86 \\
birth weight & 0.30 & 0.11 & -0.46 & 0.69 & 0.86 & 0.33 \\
fetal growth & 0.30 & 0.11 & -0.46 & 0.70 & 0.86 & 0.33 \\
\hline Observations & 0.33 & 0.09 & 0.45 & 0.67 & 1.06 & 0.33 \\
Sargan Test & 192 & 192 & 192 & 192 & 192 & 192 \\
P-vaule & 3.979 & 4.081 & 4.851 & 2.757 & 10.119 & 4.523 \\
\hline Data Source: Samp & 0.5524 & 0.5378 & 0.4343 & 0.737 & 0.0719 & 0.47676 \\
\hline
\end{tabular}

Data Source: Sample drawn from the GSOEP 2003-2005. Standard Errors are in parentheses: All models include child's gender, child's age, siblings, mother's height, mother's working hours, mother's education, mother's nationality, institutional child care, parental activity, meal, speak German with the child, parents married, availability of a garden and municipality size. ***significant at $1 \%$ level; ** significant at $5 \%$ level; *significant at $10 \%$ level. Own calculation.

dren are separated from their mothers for the first time. Hence, these associations might not persist for a longer time spend in the kindergarten.

As expected, for most skills we find a positive and significant impact of stage specific parental activities on the child's skills in the third stage. The more often and the more types of activities parents undertake with their child, the higher the current cognitive and noncognitive skills. The impact of this activities differs between skills. For instance, verbal skills are positively affected through parental activities and have an elasticity of 0.20 percent, but parental activities have no impact on the motor skill. Another difference between the formation of skills presented in Table 7 and the formation of skills presented in Table 8 is that parents' activities have no measureable influence on the development of a child's personality traits. Therefore no single investment will affect each skill in the same manner which implies also that educational policies needs differentiation. 
Timing of investment matters. While a regular nutrition enhances skills at the second stage, there is no significant association between regular nutrition and skill development at the third stage. The availability of a garden has a positive and significant impact on child's verbal, motor and social skill development. Interestingly, children who grow up in large municipalities attain poorer skill outcomes than children who grow up in small municipalities. Both of these environmental factors have no impact on the development of child's personality traits neither at the age of 3-18 months nor at the age of 26-42 months.

Gender differences for the child's satisfaction, crying behavior and meta skill are significant. Whereas girls attain significant higher social and everyday skills than boys at the third stage, there are no gender differences for child's cognitive skills. Growing up without siblings seems to have no measurable influence for the skill formation process without one exception. Single children have significant lower social skills. Finally the verbal, motor and everyday skills increase with child's age. For sensitivity reasons all models presented in Table 7 and 8 have been estimated excluding all children below 28 months and above 40 months. Table A10 and A11 (Appendix) report our main parameter of interest. Since the estimation results are very similar to the overall sample the findings can be regarded as robust with respect to the age of the children included in the estimation sample.

\section{Concluding remarks}

Self-productivity in association with the dramatic speed of learning and skill formation is the main reason that early childhood has a shaping role for human capital formation and inequality over the life cycle. It is the fundamental principle that is responsible for the cumulative and synergetic nature of human capital formation (Cunha and Heckman; 2007). In this study we investigate self-productivity within a three stage skill formation model in early childhood. Based on the representative German Socio-Economic Panel for the years 2002-2005, indicators of cognitive and noncognitive skills are observed from birth until the age of three years. So the paper sheds empirical light on the magnitude of self-productivity and the intergenerational transmission of human capital in early childhood.

Our findings indicate that both, acquired skills at previous stage and parental investments, contribute to the skill formation process. We find evidence on selfproductivity between the skill indicators at birth, at the age of 3-18 months and 
at the age of 26-42 months. Evaluated at the sample mean a one percent increase in birth weight leads to an 0.34 percent increase in child's noncognitive skills and to an 0.64 percent increase in child's health until the age of 18 months. Between the second and third stage, a one percent increase in child's noncognitive skills leads to an 0.58 percent increase in child's cognitive skills (verbal skills) and to an 1.04 percent increase in child's noncognitive skills (everyday skills). The empirical results suggest strong synergies between child's health and child's noncognitive skills.

At the second stage father's support, mother's physical and mental health as well as nutrition have a positive influence on the child's noncognitive skill development. Our findings at the end of early childhood indicate that no single investment could affect each type of skill in the same manner. Rather different types of skills require different types of investments. For instance, we find a positive return of mother's education on verbal skills, which amplify skill formation at later stages via self-productivity. Between 26-42 months we find no influence on mother's labor force participation on skill formation process. The institutional child care improved child's social and everyday skills, but has no influence on child's cognitive skill development. Finally, we find differences in returns on investments, depending on timing of investments. We regard our empirical approach as a step for a more comprehensive analysis of self-productivity with improved data and methods. The paper may also be helpful for finding bridges between studies based on "objective" skill measures, such as birth weight or achievement test scores, and "subjective" measures such as maternal ratings. A recent study on the relationship between birth weight and socio-economic outcomes in adulthood concluded: "Our estimates suggest eliminating birth weight differences between socioeconomic groups would have sizeable effects on labor market outcomes of children from poorer families" (Black et al.; 2007).

Our empirical investigation of self-productivity in the first three years of childhood sheds some light on the causal relationship between birth weight on skill outcomes. On the one hand the significant magnitude of self-productivity in early childhood suggests that strong compensatory effort is needed to help disadvantaged children already in the first three years. On the other hand improvements in nutrition for eliminating birth weight differences will be more effective if they are combined with effective parental investments at later stages. For fostering human capital more attention should be paid to the quality of the early parent-child interaction. This includes emotion and nutrition. Both factors contribute to the intergenerational transmission of human capital and inequality. 


\section{References}

Almond, D., Chay, K. and Lee, K. (2005). The Cost of Low Birth Weight, Quarterly Journal of Economics 120 (3): 1031-1083.

Barker, D. (1992). Fetal and infant origins of adult disease, London, MBJ Books.

Barker, D., Eriksson, J., Forson, T., Osmond, C. and Tuomilehto, J. (2000). Fetal and Childhood Growth and Hypertension in Adult Life, Journal of the American Heart Association 36: 67-72.

Barker, D., Eriksson, J., Forson, T., Osmond, C. and Uutela, A. (2001). Size at birth and resilience to effects of poor living conditions in adult life: longitudinal study, BMJ Journals 323: 1-6.

Ben-Porath, Y. (1967). The Production of Human Capital and the Life of Earnings, Journal of Political Economy 75: 352-365.

Black, S. E., Devereux, P. J. and Salvanes, K. (2005). Why the apple doesn't fall far: Understanding the intergenerational transmission of Human Capital, American Economic Review 95 (1): 437-449.

Black, S. E., Devereux, P. J. and Salvanes, K. G. (2007). From the Cradle to the Labor Market? The Effect of Birth Weight on Adult Outcomes, Quarterly Journal of Economics 122 (1): 409-439.

Borghans, L., Duckworth, A. L., Heckman, J. J. and Weel, B. (2007). The Economics and Psychology ofd Personality, Draft Manuscript.

Case, A., Fertig, A. and Paxson, C. (2005). The Lasting Impact of Childhood Health and Circumstance, Journal of Health Economics 24 (2): 365-389.

Chevalier, A. and O'Sullivan, V. (2007). Mother's education and birth weight, IZA Discussion Paper No.2640.

Cunha, F. and Heckman, J. J. (2007). The Technology of Skill Formation, American Economic Review 97 (2): 31-47.

Cunha, F., Heckman, J. J., Lochner, L. and Masterov, D. V. (2006). Interpreting the Evidence on Life Cycle Skill Formation, in F. Welch and E. Hanushek, eds., The Handbook of the Economics of Education, Amsterdam: North-Holland. 
Cunha, J. and Heckman, J. (2006). Formulation, Identifying and Estimating the Technology of Cognitive and Noncognitive Skill Formation, Working Paper, University of Chicago.

Cunha, J., Heckman, J. and Schennach, S. (n.d.). Estimating the Technology of Cognitive and Noncognitive Skill Formation, Working Paper, University of Chicago.

Currie, J. and Hyerson, R. (1999). Is the Impact of Health Shocks Cushioned by Socioeconomic Status? The Case of Low Birth Weight, American Economic Review 89: 245-250.

Currie, J. and Moretti, E. (2003). Mother's Education and the Intergenerational Transmission of Human Capital. Evidence from College Openings, Quarterly Journal of Economics 118 (4): 1495-1532.

Currie, J. and Stable, M. (2004). Child Mental Health and Human Capital Accumulation: The Case of ADHD, NBER Working Paper No. 10435.

Gamble, W. C., Ramakumar, S. and Diaz, A. (2007). Maternal and paternal similarities and differences in parenting: An examination of mexican-american parents of young children, Early Childhood Research Quarterly 22 (1): 72-88.

Grimm, H. (1999). Störungen der Sprachentwicklung: Grundlagen- UrsachenDiagnose- Intervention- Prävention, Göttingen, Hofgrefe.

Haisken-DeNew, J. and Frick, J. R. (2005). DTC Desktop Companion to the German Socio-Economic Panel (SOEP), DIW Berlin.

Heckhausen, J. and Heckhausen, H. (2006). Motivation und Entwicklung, in J. Heckhausen and H. Heckhausen, eds., Motivation und Handeln. Berlin: Springer Verlag.

Holodynski, M. (2005). Am Anfang war der Ausdruck. Meilensteine und Mechanismen der Emotionsentwicklung, Psychologie in Erziehung und Unterricht 52 (4): 229-249.

Laucht, M. (2005). Die langfristigen Folgen früher Entwicklungsrisiken: Ergebnisse der Mannheimer Längsschnittsstudie zu Risiko- und Schutzfaktoren, in P. Arnoldy and B. Traub, eds., Sprachentwicklungsstörungen früh erkennen und behandeln. 
Lunde, A., Melve, K., Gjessing, H., Skjaerven, R. and Irgens, L. (2007). Genetic and Environmental Influences on Birth Weight, Birth Length, Head Circumference, and Gestational Age by Use of Population-based Parent-Offspring Data, American Journal of Epidemiology 165 (7): 734-741.

Magnuson, K., Ruhm, C. and Waldfogel, J. (2007). The persistence of preschool effects: Do subsequent classroom experiences matter, Early Childhood Research Quarterly 22 (1): 18-38.

OECD (2004). OECD Health Data 2004: A Comparative Analysis of 30 Countries OECD. Definition and Methods, Paris.

Oreopoulos, P., Stabile, M., Walld, R. and Roos, L. (2006). Short, Medium, and Long Term Consequences of Poor Infant Health: An Analysis Using Siblings and Twins, NBER Working Paper No.11998.

Praag, B. V. (1991). Ordinal and Cardinal Utility: An integration of the Two Dimensions of the Welfare Concept, Journal of Econometrics 50 (1-2): 69-89.

Reichman, N. (2005). Low Birth Weight and School Readiness, The Future of Children 15 (1): 91-116.

Siantz, M. L. D. and Smith, M. (1994). Parental factors correlated with developmental outcome in the migrant head start child, Early Childhood Research Quarterly 9 (3-4): 481-503.

Solon, G. (1999). Intergenerational Mobility in the Labor Market, in O. Ashenfelter and D. Card, eds.,Handbook of Labor Economics. Volume III, Part I. Amsterdam, North-Holland.

Sparrow, S., Balla, D. and Cicchetti, D. (1984). Vineland Adaptive Behavior Scale: Interview edition survey form, Circle Pines, MV: American Guidance Service.

Steigleider, P., Laucht, M., Esser, G. and Schmidt, M. H. (2002). Beeinträchtigte kognitive und motorische Leistungen bei 8jährigen Kindern mit sehr niedrigem Geburtsgewicht, Zeitschrift für klinische Psychologie und Psychotherapie 31 (3): 204-212.

Tracy, R. (2000). Sprache und Sprachentwicklung. Was wird erworben?, in: H. Grimm, eds., Sprachentwicklung, Enzyklopädie der Psychologie, Hofgrefe, Göttingen, 3-39. 


\section{A Appendix}

Table A1: The distribution of a child's skills at the second stage

\begin{tabular}{lllll}
\hline \hline Skill indicators (in \%) & 12.5 & 37.5 & 62.5 & 87.5 \\
\hline health & 2.41 & 9.48 & 32.42 & 55.69 \\
satisfaction & 0.69 & 1.03 & 23.11 & 75.17 \\
cry & 1.38 & 6.38 & 45.00 & 47.24 \\
console & 1.03 & 1.90 & 32.76 & 64.31 \\
activity & 0 & 1.72 & 17.07 & 81.21 \\
\hline \hline
\end{tabular}

Data Source: Sample drawn from the GSOEP 2003-2005. Own calculation.

Table A2: The distribution of a child's skills at the third stage

\begin{tabular}{lllll}
\hline \hline Skill indicators (in \%) & 12.5 & 37.5 & 62.5 & 87.5 \\
\hline health & 3.65 & 9.38 & 25.00 & 61.97 \\
satisfaction & 0 & 0.52 & 22.92 & 76.56 \\
cry & 2.08 & 6.77 & 57.29 & 33.86 \\
console & 1.04 & 2.60 & 42.19 & 54.17 \\
activity & 0 & 20.31 & 0 & 79.69
\end{tabular}

Data Source: Sample drawn from the GSOEP 2003-2005. Own calculation.

Table A3: The child's skills at the third stage

\begin{tabular}{|c|c|c|}
\hline Skill indicators & Statement & Scale \\
\hline verbal & $\begin{array}{l}\text { 1.Understands brief instructions such as "go get your shoes" } \\
\text { 2.Forms sentences with at least two words 3.Speaks in full } \\
\text { sentences (with four or more words) 4.Listens attentively } \\
\text { to a story for five minutes or longer 5.Passes on simple } \\
\text { messages such as "dinner is ready" }\end{array}$ & $\begin{array}{l}\text { Vineland Be- } \\
\text { havior Scale }\end{array}$ \\
\hline motor & $\begin{array}{l}\text { 1.Walks forwards down the stairs } 2 \text {. Open doors with the } \\
\text { door handle } 3 . \text { Climbs up playground climbing equipment } \\
\text { and other high playgrounds structures } 4 \text {.Cuts paper with } \\
\text { scissors 5.Paints/draws recognizable shapes on paper }\end{array}$ & $\begin{array}{l}\text { Vineland Be- } \\
\text { havior Scale }\end{array}$ \\
\hline social & $\begin{array}{l}\text { 1.Calls familiar people by name, for example, says } \\
\text { "mommy" and "daddy" or uses the father's first name } 2 . \text { Par- } \\
\text { ticipates in games with other children } 3 . \text { Gets involved in } \\
\text { role-playing games ("playing pretend") 4.Shows a special } \\
\text { liking for particular playmates or friends } 5 \text {.Calls his/her } \\
\text { own feelings by name, e.g. "sad","happy" "scared" }\end{array}$ & $\begin{array}{l}\text { Vineland Be- } \\
\text { havior Scale }\end{array}$ \\
\hline everyday & $\begin{array}{l}\text { 1.Uses a spoon to eat, without assistance and without drip- } \\
\text { ping } 2 \text {. Blows his/her nose without assistance } 3 \text {. Uses the toi- } \\
\text { let to do "number two" } 4 \text {.Puts on pants and underpants } \\
\text { the right way around } 5 \text {.Brushes his/her teeth without as- } \\
\text { sistance }\end{array}$ & $\begin{array}{l}\text { Vineland Be- } \\
\text { havior Scale }\end{array}$ \\
\hline
\end{tabular}


Table A4: Parental' activities at the third stage

\begin{tabular}{lllll}
\hline \hline Statements & Daily & $\begin{array}{l}\text { Several times } \\
\text { per week }\end{array}$ & $\begin{array}{l}\text { At least once a } \\
\text { week }\end{array}$ & Never \\
\hline singing children's songs with or to the child & 40.62 & 32.29 & 17.19 & 9.90 \\
taking walks outdoors & 60.94 & 30.21 & 7.29 & 1.56 \\
painting or doing arts and crafts & 22.92 & 44.27 & 27.08 & 5.73 \\
reading or telling stories & 57.81 & 27.08 & 9.90 & 5.21 \\
looking at picture books & 66.67 & 23.44 & 7.81 & 2.08 \\
going to the playground & 14.06 & 36.46 & 27.60 & 21.88 \\
visiting other families with children & 1.56 & 31.26 & 52.08 & 15.10 \\
going shopping with the child & 9.38 & 50.52 & 36.45 & 3.65 \\
watching television or video with the child & 27.60 & 38.02 & 16.67 & 17.71 \\
\hline \hline
\end{tabular}

Data Source: Sample drawn from the GSOEP 2005. Own calculation. 
Table A5: Birth weight, $\ln$ (birth weight), fetal growth and NBW for the pooled sample

\begin{tabular}{|c|c|c|c|c|}
\hline & birth weight & $\ln ($ birth weight $)$ & fetal growth & $\mathrm{NBW}(\mathrm{dF} / \mathrm{dx})$ \\
\hline \multicolumn{5}{|c|}{ Newborn's characteristics $S_{0}$} \\
\hline \multirow[t]{2}{*}{ Male } & $141.97^{* * *}$ & $0.04^{* * *}$ & $3.21^{* * *}$ & 0.018 \\
\hline & $(37.97)$ & $(0.01)$ & $(0.88)$ & $(0.014)$ \\
\hline \multirow[t]{2}{*}{ No Sibling } & $-143.35^{* * *}$ & $-0.05^{* *}$ & -3.63 & $-0.042^{* *}$ \\
\hline & $(43.17)$ & $(0.01)$ & $(1.00)$ & $(0.018)$ \\
\hline \multirow[t]{2}{*}{ Twin } & $-947.40^{* * *}$ & $-0.32^{* * *}$ & $-20.65^{* * *}$ & $-0.48^{* * *}$ \\
\hline & $(117.55)$ & $(0.04)$ & $(2.70)$ & $(0.12)$ \\
\hline \multicolumn{5}{|c|}{ Mother's "investment" $I_{1}$} \\
\hline \multirow[t]{2}{*}{ Mother's height } & $15.52^{* * *}$ & $0.005^{* * *}$ & $0.36^{* * *}$ & $0.003^{* * *}$ \\
\hline & $(2.98)$ & $(0.001)$ & $(0.07)$ & $(0.001)$ \\
\hline \multirow[t]{2}{*}{ Mother's health } & $-15.04^{* * *}$ & $-0.006^{* * *}$ & $-0.28 * * *$ & $-0.002^{* * *}$ \\
\hline & $(2.57)$ & $(0.001)$ & $(0.06)$ & $(0.001)$ \\
\hline \multirow[t]{2}{*}{ Fetal Environment } & -6.42 & 0.005 & -0.72 & $0.04^{* *}$ \\
\hline & $(44.20)$ & $(0.01)$ & $(1.02)$ & $(0.02)$ \\
\hline \multirow[t]{2}{*}{ Mother's age } & -40.43 & -0.01 & $-1.41^{*}$ & -0.018 \\
\hline & $(32.19)$ & $(0.01)$ & $(0.76)$ & $(0.014)$ \\
\hline \multirow[t]{2}{*}{ Mother's age squared } & 0.70 & 0.0002 & $0.02^{*}$ & 0.0003 \\
\hline & $(0.52)$ & $(0.0002)$ & $(0.01)$ & $(0.0002)$ \\
\hline \multirow[t]{2}{*}{ Mother's education } & 5.27 & 0.001 & 0.04 & -0.002 \\
\hline & $(0.005)$ & $(0.003)$ & $(0.19)$ & $(0.003)$ \\
\hline \multirow[t]{2}{*}{ Mother German } & -13.41 & -0.01 & -1.43 & 0.03 \\
\hline & $(63.69)$ & $(0.02)$ & $(1.48)$ & $(0.014)$ \\
\hline \multirow[t]{2}{*}{ Municipality size } & -1.68 & -0.0002 & -0.03 & 0.004 \\
\hline & $(10.52)$ & $(0.004)$ & $(0.24)$ & $(0.004)$ \\
\hline \multirow[t]{2}{*}{ Constant } & $1371.88^{* * *}$ & $7.50 * * *$ & $49.59^{* * *}$ & - \\
\hline & $(707.43)$ & $(0.24)$ & $(16.50)$ & - \\
\hline F-test $/ \mathrm{Chi}^{2}$ & $15.35^{* * *}$ & $16.22^{* * *}$ & $13.59^{* * *}$ & 85.50 \\
\hline Adjusted/Pseudo $R^{2}$ & 0.1780 & 0.1868 & 0.1624 & 0.2379 \\
\hline
\end{tabular}

Data Source: Sample drawn from the GSOEP 2003-2005. Standard Errors are in parentheses: $* * *$ significant at $1 \%$ level; ${ }^{* *}$ significant at $5 \%$ level; ${ }^{*}$ significant at $10 \%$ level. Own calculation. 
Table A6: OLS results (3-18 months) for self-productivity and investment, Likert Scale

\begin{tabular}{|c|c|c|c|c|c|c|}
\hline & Health & Satisfaction & Cry & Console & Activity & $\begin{array}{l}\text { Meta } \\
\text { Skill }\end{array}$ \\
\hline Skill $(\mathrm{t}=1)$ & $11.91^{* * *}$ & 3.34 & 4.42 & 3.58 & $5.11^{* *}$ & $5.67^{* * *}$ \\
\hline (Birth weight) & $(4.43)$ & $(3.00)$ & $(3.87)$ & $(3.45)$ & $(2.59)$ & $(2.17)$ \\
\hline \multirow{3}{*}{$\begin{array}{l}\text { Strong father's sup- } \\
\text { port }\end{array}$} & \multicolumn{4}{|c|}{ Stage specific investment $I_{2}$} & & \\
\hline & 1.90 & $2.74^{* *}$ & $3.54^{* *}$ & $4.63^{* * *}$ & $3.23^{* * *}$ & $3.21^{* *}$ \\
\hline & $(1.76)$ & $(1.19)$ & $(1.53)$ & $(1.32)$ & $(1.03)$ & $(0.86)$ \\
\hline Post fetal- & $6.34^{* * *}$ & $3.18^{* * *}$ & $5.31^{* * *}$ & $2.33^{*}$ & 0.21 & $3.47^{* * *}$ \\
\hline environment & $(1.80)$ & $(1.22)$ & $(1.58)$ & $(1.36)$ & $(1.05)$ & $(0.88)$ \\
\hline \multirow[t]{2}{*}{ Regular meal } & $6.57^{* * *}$ & 0.70 & $4.22^{*}$ & $6.73^{* * *}$ & 1.45 & $3.93^{* * *}$ \\
\hline & $(2.59)$ & $(1.75)$ & $(2.27)$ & $(1.96)$ & $(1.52)$ & $(1.27)$ \\
\hline \multirow[t]{2}{*}{ Constant } & -16.03 & 38.34 & -26.19 & 0.61 & 33.70 & 6.09 \\
\hline & $(37.93)$ & $(25.66)$ & $(33.19)$ & $(28.68)$ & $(22.17)$ & $(18.55)$ \\
\hline Observations & 580 & 580 & 580 & 580 & 580 & 580 \\
\hline F-test & $2.89^{* * *}$ & $2.13^{* * *}$ & $3.38^{* * *}$ & $4.29 * * *$ & $2.97 * * *$ & $5.32^{* * *}$ \\
\hline
\end{tabular}

Data Source: Sample drawn from the GSOEP 2003-2005. Standard Errors are in parentheses: All models include child's gender, child's age, siblings, mother's height, mother's education, mother's nationality, availability of a garden and municipality size. ${ }^{* * *}$ significant at $1 \%$ level; ${ }^{* *}$ significant at $5 \%$ level; * significant at $10 \%$ level. Own calculation.

Table A7: 2SLS results (3-18 months) for self-productivity and investment, Likert Scale

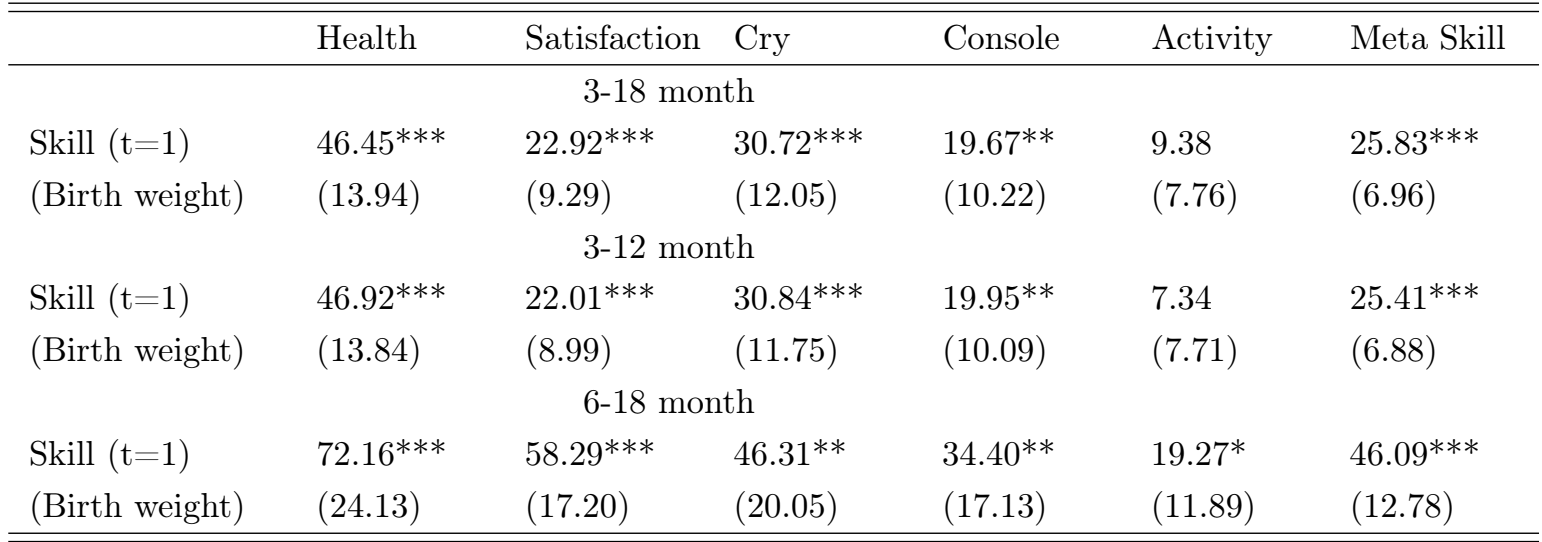

Data Source: Sample drawn from the GSOEP 2003-2005. Standard Errors are in parentheses: All models include child's gender, child's age, siblings, mother's height, mother's education, mother's nationality, availability of a garden, municipality size, regular meal, strong father's support and post-fetal environment. ${ }^{* * *}$ significant at $1 \%$ level; ${ }^{* *}$ significant at $5 \%$ level; ${ }^{*}$ significant at $10 \%$ level. Own calculation. 
Table A8: OLS results (26-42 months) for self-productivity and investment, Vineland Scale

\begin{tabular}{lllll}
\hline \hline & Verbal & Motor & Social & Everyday \\
\hline Meta Skill $(\mathrm{t}=2)$ & $0.18^{* *}$ & 0.13 & $0.20^{* *}$ & 0.20 \\
& $(0.09)$ & $(0.09)$ & $(0.09)$ & $(0.13)$ \\
\hline \multirow{2}{*}{ Mother's education } & General & and stage specific investment $I_{3}$ & \\
& $0.56^{*}$ & 0.46 & 0.24 & -0.16 \\
Institutional care & $(0.29)$ & $(0.31)$ & $(0.30)$ & $(0.46)$ \\
& 0.04 & 0.05 & $0.15^{* *}$ & $0.19^{* *}$ \\
Parental activity & $(0.06)$ & $(0.06)$ & $(0.06)$ & $(0.09)$ \\
Garden & $0.69^{* * *}$ & 0.21 & $0.38^{* *}$ & 0.44 \\
Constant & $(0.18)$ & $(0.19)$ & $(0.18)$ & $(0.28)$ \\
& $5.47^{* * *}$ & $5.50^{* * *}$ & $6.20^{* * *}$ & 2.70 \\
\hline Observations & $(1.86)$ & $(1.97)$ & $(1.87)$ & $(2.94)$ \\
F-test & 14.63 & 16.29 & $45.56^{* *}$ & 5.22 \\
\hline \hline Data Sour & $(20.11)$ & $(21.29)$ & $(20.25)$ & $(31.82)$ \\
\hline
\end{tabular}

Data Source: Sample drawn from the GSOEP 2003-2005. Standard Errors are in parentheses: All models include child's gender, child's age, siblings, mother's height, mother's working hours, mother's nationality, regular meal, speak German with the child, parents married and municipality size.

*** significant at $1 \%$ level; **significant at $5 \%$ level; * significant at $10 \%$ level. Own calculation. 
Table A9: OLS results (26-42 months) for self-productivity and investment, Likert Scale

\begin{tabular}{|c|c|c|c|c|c|c|}
\hline & Health & Satisfaction & Cry & Console & Activity & $\begin{array}{l}\text { Meta } \\
\text { Skill }\end{array}$ \\
\hline Health $(\mathrm{t}=2)$ & $\begin{array}{l}0.36 * * * \\
(0.36)\end{array}$ & & & & & \\
\hline Satisfaction $(t=2)$ & & $\begin{array}{l}0.05 \\
(0.08)\end{array}$ & & & & \\
\hline Cry $(t=2)$ & & & $\begin{array}{l}0.16^{* *} \\
(0.07)\end{array}$ & & & \\
\hline Console $(t=2)$ & & & & $\begin{array}{l}0.40^{* * *} \\
(0.08)\end{array}$ & & \\
\hline Activity $(\mathrm{t}=2)$ & & & & & $\begin{array}{l}0.35^{* * *} \\
(0.12)\end{array}$ & \\
\hline Meta skill $(t=2)$ & & & & & & $\begin{array}{l}0.40^{* * *} \\
(0.08)\end{array}$ \\
\hline
\end{tabular}

\begin{tabular}{lllllll}
\hline & \multicolumn{7}{l}{ General and stage specific investment $I_{3}$} & & \\
Mother's education & 0.83 & -0.16 & 0.57 & 0.36 & $1.67^{* * *}$ & $0.69^{* * *}$ \\
& $(0.59)$ & $(0.33)$ & $(0.51)$ & $(0.43)$ & $(0.59)$ & $(0.27)$ \\
Institutional care & $-0.24^{* *}$ & $-0.12^{*}$ & -0.08 & -0.14 & -0.15 & $-0.16^{* * *}$ \\
& $(0.12)$ & $(0.07)$ & $(0.10)$ & $(0.09)$ & $(0.12)$ & $(0.06)$ \\
Parental activity & -0.26 & 0.05 & 0.10 & $0.47^{*}$ & $0.75^{* *}$ & 0.18 \\
& $(0.36)$ & $(0.20)$ & $(0.31)$ & $(0.26)$ & $(0.36)$ & $(0.16)$ \\
Garden & -3.10 & $3.50^{*}$ & -0.63 & -3.56 & 0.91 & -0.91 \\
Constant & $(3.74)$ & $(2.08)$ & $(3.21)$ & $(2.73)$ & $(3.76)$ & $(1.70)$ \\
& -9.65 & $102.97^{* * *}$ & $71.54^{* *}$ & 26.69 & $78.83^{* *}$ & $47.85^{* * *}$ \\
\hline Observations & $(39.97)$ & $(22.60)$ & $(33.82)$ & $(29.15)$ & $(40.14)$ & $(18.42)$ \\
F-test & 192 & 192 & 192 & 192 & 192 & 192 \\
\hline \hline Data Source Sample & 2.40 & $1.88^{* *}$ & 1.12 & $3.04^{* * *}$ & $2.20^{* * *}$ & $3.29^{* * *}$ \\
\hline
\end{tabular}

Data Source: Sample drawn from the GSOEP 2003-2005. Standard Errors are in parentheses: All models include child's gender, child's age, siblings, mother's height, mother's working hours, mother's nationality, regular meal, speak German with the child, parents married and municipality size. ${ }^{* * *}$ significant at $1 \%$ level; ${ }^{* *}$ significant at $5 \%$ level; ${ }^{*}$ significant at $10 \%$ level. Own calculation. 
Table A10: 3SLS results (26-42 months) for self-productivity and investment, Vineland Scale

\begin{tabular}{llllc}
\hline \hline & Verbal & Motor & Social & Everyday \\
\hline \multirow{3}{*}{ Skill $(\mathrm{t}=2)$} & $26-42$ month & & & \\
& $0.54^{* * *}$ & $0.44^{* *}$ & $0.63^{* * *}$ & $0.72^{* * *}$ \\
& $(0.21)$ & $(0.22)$ & $(0.21)$ & $(0.33)$ \\
& $28-40$ month & & & \\
Skill $(\mathrm{t}=2)$ & $0.41^{*}$ & $0.40^{*}$ & $0.43^{*}$ & $0.73^{* *}$ \\
& $(0.23)$ & $(0.24)$ & $(0.23)$ & $(0.37)$ \\
\hline
\end{tabular}

Data Source: Sample drawn from the GSOEP 2003-2005. Standard Errors are in parentheses: All models include child's gender, child's age, siblings, mother's height, mother's working hours, mother's education, institutional child care, parental activity, mother's nationality, regular meal, speak German with the children, parents married, municipality size and the availability of a garden. $* * *$ significant at $1 \%$ level; ** significant at $5 \%$ level; ${ }^{*}$ significant at $10 \%$ level. Own calculation.

Table A11: 3SLS results (26-42 months) for self-productivity and investment, Likert Scale

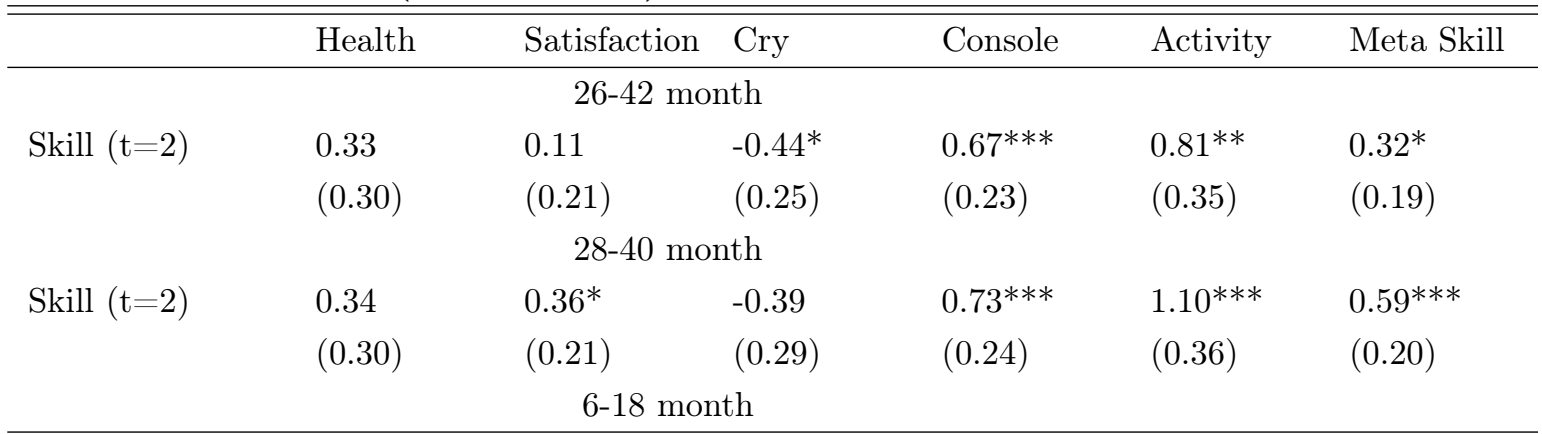

Data Source: Sample drawn from the GSOEP 2003-2005. Standard Errors are in parentheses: All models include child's gender, child's age, siblings, mother's height, mother's working hours, mother's education, institutional child care, parental activity, mother's nationality, regular meal, speak German with the child, parents married, municipality size and the availability of a garden. *** significant at $1 \%$ level; ${ }^{* *}$ significant at $5 \%$ level; * significant at $10 \%$ level. Own calculation. 